\title{
20. 高出力型無電極蛍光ランプ点灯システムの開発
}

\author{
增本進吾 牧村 紳司 山本 正平熊谷 祐二 城戸 大志 岡本太志 \\ （松下電工株式会社）
}

1.はじめに

主に装飾用途で使用される $1000 \mathrm{~lm}$ 以下の低出力型無電極蛍光ランプを既に開発しているが、より高出力 型無電極蛍光ランプを開発するためには、輻射ノイズおよび効率などが課題となる。

今回、これらの課題を克服し、水銀灯 $100 \mathrm{~W}$ 相当の光出力をもつ高出力型無電極蛍光ランプ点灯システム を開発し実用的特性を得たので、その点灯システムの構成および主特性について報告する。

\section{2. 構成}

図 1 に点灯システムを示す。回路ユニットとランプユニット は器具設計の自由度を考慮し、同軸ケーブルで分離している。 誘導コイルは、無電極蛍光ランプの外周に周回した空芯コイル である。

図 2 に回路ブロック図を示す。電源回路 1 はD級増幅回路、 電源回路 2 は発振回路, 駆動回路, 保護回路の電源となる直流電 圧を出力する。発振回路からの $13.56 \mathrm{MHz}$ の高周波信号を駆動回 路に供給し、2つのスイッチング素子が直列に接続されたD級 増幅回路を動作させる。主増幅回路をD級増幅回路とし、駆動 回路の出力波形を改善して高効率化を図っているり。D級增幅 回路で増幅された高周波電力は、同軸ケーブル，マッチング回 路を介して誘導コイルに伝わり、誘導コイルで発生した高周波 電磁界により無電極蛍光ランプを点灯させる。マッチング回路 は、始動時に誘導コイルへ十分な高電圧を発生し、且つ、安定 時に所望の電力を効率良く負荷へ供給する条件を満たすよう設 計している2)。無負荷などの異常時には間欠発振させる保護回 路を付加した。

無電極蛍光ランプの実用化への課題の一つである輻射ノイズ に関しては、ケース構造の最適化，高周波スイッチングノイズ のシールド， 3 重同軸ケーブル, クランプフィルタの使用などの 手段により対策した。その結果、従来ノイズ対策で用いられた ランプ周辺の金属メッシュ³)不要にした。

\section{3. 特性}

開発した高出力型無電極蛍光ランプ点灯システムの主な特性 は表 1 に示す通りである。入力電力 $64 \mathrm{~W}$, 光出力 $4550 \mathrm{~lm}$, 総合効

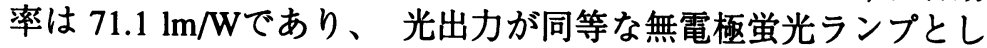
ては世界最高の効率を達成した。入力電流高調波歪みは、Class Cに準拠し、また、一般の蛍光ランプと比較して、 $-20^{\circ} \mathrm{C} \sim 40^{\circ} \mathrm{C}$ の広い温度範囲で使用可能である。

\section{4.まとめ}

今回、高効率な高出力型無電極蛍光ランプ点灯システムを開 発した。本無電極蛍光ランプは光出力が $45501 \mathrm{~m}$ であるため、街 路灯, トンネル灯などの照明用途における普及が期待できる。

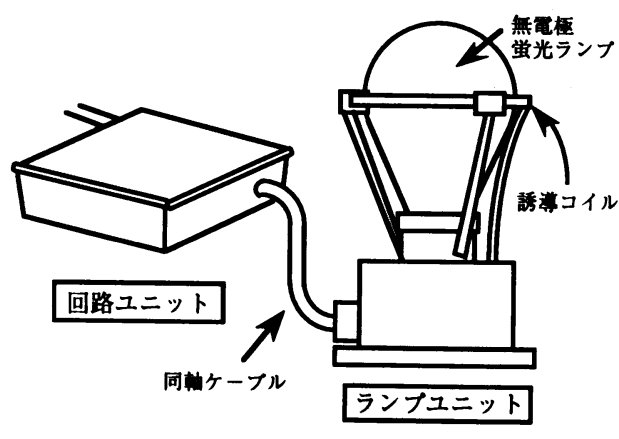

図 1 点灯システム

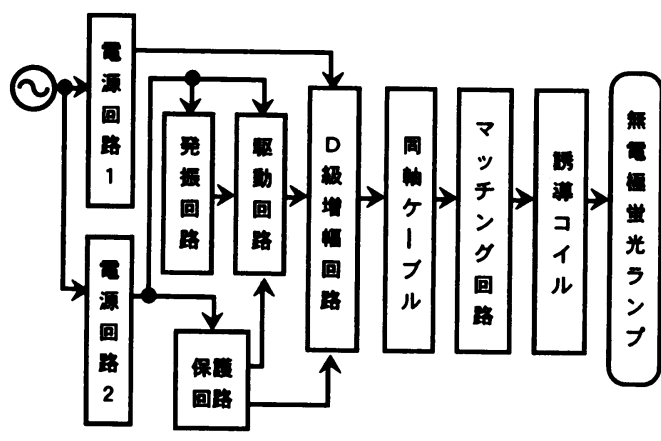

図 2 回路ブロック図

表 1 主特性

\begin{tabular}{|c|c|}
\hline 入力電圧 & $\mathrm{AC100} \mathrm{V}$ \\
\hline 入力電流高調波昰み & Class C 準拠 \\
\hline 入力電力 & $64 \mathrm{~W}$ \\
\hline 出力電力 & $50 \mathrm{~W}$ \\
\hline 光出力 & $4550 \mathrm{~lm}$ \\
\hline 動作周波数 & $13.56 \mathrm{MHz}$ \\
\hline 使用温度範囲 & $-20^{\circ} \mathrm{C} \sim 40^{\circ} \mathrm{C}$ \\
\hline ランプ寿命 & $\begin{array}{c}60000 \text { 時間 } \\
\text { (光束維持率70\%時) }\end{array}$ \\
\hline
\end{tabular}

参考文献 1) 牧村他：無電極蛍光ランプ点灯回路における高効率化の一検討, 平成10年度照明学会全国大会 No.21 2) 山本他：無電極蛍光ランプ点灯回路における電力安定化の一検討, 平成11年度照明学会全国大会 No.30 3) 西田他：無電極蛍光ランプユニットの開発, 平成9年度照明学会全国大会 No.27

Development of lighting system for high power electrodeless fluorescent lamps

Shingo Masumoto, Shinji Makimura, Shohei Yamamoto, Yuji Kumagai, Hiroshi Kido, Futoshi Okamoto 